\title{
Legal Gender Meets Reality: A Socio-Legal Children's Perspective
}

\section{Anniken Sørlie}

\begin{abstract}
Under Norwegian law, the registration of children at birth is regarded as the minimum guarantee for their enjoyment of children's rights. But how does the legal gender assigned at registration impact on gender non-conforming children's and adolescents' experiences? How does the regulation of gender assignment under Norwegian law chime with the human rights of gender non-conforming children, particularly the right to respect for one's private life and non-discrimination? Are there any possibilities for children to change their legal gender? This article gives voice to the experiences, challenges, and wishes of gender non-conforming children. The aim is to show how legal gender intertwines with feelings of recognition, selfconfidence, self-respect, and self-esteem.
\end{abstract}

\section{Keywords}

Birth registration; children; human rights; legal gender; recognition; transgender

\section{Introduction}

Mum, would you love me if I had short hair? Mum, do you love me no matter what? No matter what I wear? Even though I won't wear a dress any more? ${ }^{1}$

Daniel, who at birth was registered as a girl, asked these questions to prepare his mother for his prospective coming-out - a process which he began by hinting at his gender identity. Daniel was tired of living his life as somebody he was not. If he were to go on living, he needed to live as Daniel. He told his mother this explicitly some years later - at the age of 16 . Her unconditional support came as a great relief. From his father, he experienced misrecognition - in his father's eyes, Daniel was still his little princess. When telling his father, he started the conversation by saying 'Dad, please don't hate me. I want to be happy.' This is telling of the fear of misrecognition and rejection many gender non-conforming children and adolescents feel. Unfortunately, largely due to the gender norms of the society in which we live, this fear is often well-founded.

\footnotetext{
${ }^{1}$ Informant 'Daniel', interviewed in 2015. I refer to the informants in accordance with their expressed gender identity. All names are pseudonyms. The translations are my own.
} 
Judith Butler writes that a norm is neither a rule nor a law. 'A norm operates within social practices as the implicit standard of normalization. ${ }^{2}$ It is usually difficult to read. The norm governs the domain of the social, and determines which practices and actions can be recognisable. ${ }^{3}$ We live our lives in societies where gender norms, religious norms and norms on sexuality intertwine. These norms impact on our capabilities and experiences, though norms are neither laws nor rules. Law, however, is never inseparable from prevailing norms. In democracies, law emanates from the citizens who navigate their lives amid these norms. It is within this context that our identities are formed. For transgender people, identity formation takes place alongside provisions on legal gender. The norms on which the provisions are based may influence whether or not transgender children gain parental support, and consequently, their ability to freely shape their identity. Lack of support can lead to disputes between parents and the child, where the former's rights conflict with the rights of the child. Martha Albertson Fineman argues that institutions like the family, school, and community, where children are supposed to build their resilience, are failing young $\mathrm{LGBT}^{4}$ people. The failure arises from a structural disadvantaging of children, while family privacy and parental rights are valorised. Children are an especially vulnerable group in society. An LGBT child experiences a double vulnerability as both a child and an LGBT person. ${ }^{5}$ Being transgender too can be challenging. Transgender people face widespread discrimination and harassment. In 2015, a Swedish inquiry into the health status of transgender people revealed that more than half of the respondents reported that they had been subjected to abusive treatment or behaviour at least once in the last three months. ${ }^{6}$

The legal gender of Norwegian citizens is marked by a gender-specific national identity number, which is assigned shortly after birth. While most Norwegians hardly ever notice that their national identity number gives information about their gender, for those children who experience a mismatch between their legal gender and their gender identity, their legal gender is a challenge. In Norway, as in many other countries, the LGBT movement has demanded an end to requirements for legal gender recognition, which they consider intrusive, such as the diagnosis of transsexualism and the irreversible removal of reproductive organs. In June 2015, the Ministry of Health and Care Services finally published a consultation paper for the first Norwegian law on legal gender recognition. ${ }^{7}$ The law proposal suggests abolishing the

\footnotetext{
2 Judith Butler, Undoing Gender (Routledge 2004) 41.

${ }^{3}$ Butler (n 2) 42.

${ }^{4}$ Lesbian, gay, bisexual, and transgender.

${ }^{5}$ Martha Albertson Fineman, 'Vulnerability, Resilience, and LGBT Youth’ (2014) 23 Temp. Pol. \& Civ. Rts. L. Rev. 307.

${ }^{6}$ Folkhälsomyndigheten, 'Hälsan och hälsans bestämningsfaktorer för transpersoner: En rapport om hälsoläget bland transpersoner i Sverige' (2015) 30.

${ }^{7}$ The Ministry of Health and Care Services, 'Høringsnotat: Forslag til lov om endring av juridisk kjønn' (15/2180, 25 June 2015).
} 
existing requirements for medical interventions for legal gender recognition. ${ }^{8}$ According to the proposal, children over 16 can apply individually to change their legal gender, whereas children between seven and 16 require parental consent.

The aim of this article is to discuss the existing and proposed Norwegian laws and regulations in the light of the lived realities of gender non-conforming children. The article aims to show how certain identities are accepted, while others are misrecognised by law, and how the law thus determines whose identities can obtain full recognition and who can freely shape their identity. It gives examples of how the law's inclusion or exclusion of identities are experienced and perceived by transgender young people. Like Jill Marshall, I see law as a key element in an individual's identity:

\begin{abstract}
Law defines; it both includes and excludes entities as human beings to be protected by human rights law. It allows, permits, protects and provides; it also recognises, misrecognises and ignores identities. In doing so, it conditions the formation of certain types of identity. Human rights law does this particularly by purporting to translate moral norms of human freedom and human dignity into legal rights given to human beings by virtue of their species. ... While somehow believing we are making our subjectivity and freely choosing our identities, we are increasingly being obliged to live in certain conformed ways, pushing out identities that do not fit with what is acceptable. ${ }^{9}$
\end{abstract}

However, unlike Marshall's book, this article takes gender non-conforming, or transgender, children's lived experiences as its starting point. Drawing inspiration from the feminist jurisprudence developed by Tove Stand Dahl, I approach these experiences through an integrated analysis of philosophical, doctrinal, and legal sources. ${ }^{10}$ The narratives give rise to a series of questions regarding the relationship between legal gender assignment and gender non-conforming children's self-confidence, self-respect, and self-esteem. According to the philosopher Axel Honneth, these forms of self-relation are fundamental to the formation of an individual's identity and to self-realisation. These different forms of self-relation are attainable through participation and recognition in the private sphere, the legal sphere, and the social sphere. All are regarded as ontogenetic developmental stages in achieving a good life. The forms of self-relations can only be attained through intersubjective recognition. ${ }^{11}$ With this as the theoretical basis for the discussion, I investigate how Norwegian law impacts on the experiences of gender non-conforming children. To do this, I present the stories of three young transgender people. The main research questions are how legal gender assignment and

\footnotetext{
${ }^{8}$ The Norwegian government will abolish medical requirements for legal gender recognition. The Ministry of Health and Care Services, 'Ny rapport om juridisk kjønn' (10 April 2015) https://www.regjeringen.no/no/aktuelt/ny-rapport-om-juridisk-kjonn/id2405435/.

9 Jill Marshall, Human Rights Law and Personal Identity (Routledge, 2014) 18, 19.

${ }^{10}$ See, eg, Tove Stang Dahl, 'Mot en fortolkende rettsteori' (1988) 101 Tidsskrift for Rettsvitenskap 54.

${ }^{11}$ Axel Honneth, Kampf um Anerkennung: Zur moralischen Grammatik sozialer Konflikte, (Suhrkamp Verlag Frankfurt am Main, 1992).
} 
change of legal gender are regulated under Norwegian law. This, consequently, begs the question: how can this regulation fit with the human rights of gender non-conforming children, particularly the right to respect for one's private life and non-discrimination? What are their narratives, and how can we understand their narratives in the light of Honneth's theory? Finally, how can his theory be applied to render experiences relating to legal gender visible, and therefore also to contribute to the human rights discussion?

Following this introduction, section II unpacks the philosophical and legal framework, on which the later analysis builds. In section III, I describe the methodology used in the article. In part IV, I present and analyse the narratives categorised in Honneth's three spheres of recognition: (1) the private sphere, (2) the legal sphere, and (3) the social sphere. This division demonstrates the complexity of recognition, and how the spheres interrelate. In section $\mathrm{V}$, I discuss two alternatives to legal gender by drawing on the analysis in the previous sections.

\section{Theoretical and Human Rights Framework}

This section provides the backdrop for the analysis of the relationship between empirical sources, describing gender non-conforming lived realities, the philosophical theory of recognition, and international and national law on the right to dignity and gender identity. I start with Honneth's theory of recognition before presenting the human rights framework applied in this article. I then give an overview of Norwegian law and practice on assignment and change of legal gender. In addition, drawing on the presentation in II.ii, I briefly outline how Norwegian administrative practice on legal gender recognition is contrary to the human rights of transgender people.

\section{II.i Theory of recognition}

Axel Honneth explicates the formal conditions for human self-realisation in his main work Kampf um Anerkennung. Zur moralischen Grammatik sozialer Konflikte. ${ }^{12}$ In this work, he refines the concept of recognition by reconstructing Hegel's model for recognition by reference to the object-relations theory of psychoanalyst Donald W Winnicott and the social psychology of philosopher, sociologist, and psychologist Georg Herbert Meads.

Human beings are, according to Axel Honneth, dependent on mutual recognition in order to develop their personal identity. ${ }^{13}$ The development of self-confidence, self-respect, and selfesteem are necessary for self-realisation and identity-formation. These modes of practical

\footnotetext{
12 Ibid.

${ }^{13}$ Rasmus Willig, Axel Honneth: Behovet for Anerkendelse: En Tekstsamling (Mogens Chrom Jacobsen (trs) and Rasmus Willig (ed), Hans Reitzels Forlag 2003) 12.
} 
relation to oneself are regarded as ontogenetic developmental stages in the attainment of the good life, or for successful human self-realisation. These positive forms of self-relation correspond to three different spheres in modern societies: (1) the private sphere, (2) the legal or judicial sphere, and (3) the social or solidarity sphere. An individual can acquire the three basic kinds of self-relation - self-confidence, self-respect, and self-esteem - through participation in each of these spheres and by establishing mutual recognition in them. Each sphere consists of intersubjective relations of recognition, where central aspect of our humanness is recognised.

The first form of recognition, love, and development of self-confidence, constitutes the condition for participation in intersubjective relations. This is the first ontogenetic stage. According to Honneth, self-confidence can only be developed in personal relations (that is, the private sphere), such as the relation between parent and child and through friendship. Emotional safety is the foundation and makes the individual capable of developing other forms of self-respect. ${ }^{14}$ Secondly, self-respect is, on the other hand, developed through universal rights and the individual's capacity to claim rights. Recognition through rights secures the autonomy of an individual. To be a possessor of rights means that the individual is respected by others. The highest level of self-respect is only attainable when a person is recognised as an individual with an autonomous legal personality. ${ }^{15}$ Thirdly, self-esteem can be attained if an individual has the feeling that they are regarded as an important contributor to society, for example because their way of life and individual skills are valued. ${ }^{16}$ This is so, according to Honneth: 'For it is only due to the cumulative acquisition of basic selfconfidence, of self-respect, and of self-esteem - provided, one after another, by the experience of those three forms of recognition - that a person can come to see himself or herself, unconditionally, as both an autonomous and an individuated being and to identify with his or her goals and desires. ${ }^{, 17}$

\section{II.ii The right to gender identity and non-discrimination under international human rights law}

The European Court of Human Rights (ECtHR) has played an important role in increasing the protection of the human rights of LGBTI persons. In the Court's early case law on the legal recognition of transgender persons' gender identity, a dissenting opinion by Judge Martens points out that:

\footnotetext{
${ }^{14}$ Axel Honneth, Kamp om Anerkjennelse: Om de sosiale konfliktenes moralske grammatikk (Lars Holm-Hansen (tr) Pax Forlag 2007) 104-116.

${ }^{15}$ Honneth, Kamp om Anerkjennelse (n 14) 117-129.

${ }^{16}$ Ibid, 138.

17 Axel Honneth, The Struggle for Recognition: The Grammar of Social Conflicts (Joel Anderson (trs), Cambridge: Polity 1995) 169.
} 
The principle which is basic in human rights and which underlies the various specific rights spelled out in the Convention is respect for human dignity and human freedom. Human dignity and human freedom imply that a man should be free to shape himself and his fate in the way that he deems best fits his personality. ${ }^{18}$

Human dignity serves as a common denominator between the theory of recognition and the right of transgender people to legal recognition. Human dignity is the basis of human rights as well as a principle for the interpretation and application of specific human rights. ${ }^{19}$ Numerous international human rights conventions refer to human dignity either in specific provisions or preambles, or by referring to other conventions, which explicitly address the dignity of all human beings. ${ }^{20}$ Paolo G Carozza asserts that, in the context of how human dignity is applied in international human rights law, human dignity is both an ontological claim and a normative and meta-legal principle, which are interrelated. It is an ontological claim concerning the status of persons. All persons have 'an equal and inherent moral value or worth.' As a normative and meta-legal principle it affirms the entitlement of all persons to have this worth protected or respected by others.

The normative content of human dignity must be seen in relation to substantive rights. Carozza identifies four main principles which sheds light on the normative content of human dignity: (1) integrity, (2) equality and non-discrimination, (3) satisfaction of basic material needs, and (4) personal autonomy. ${ }^{21}$ A closer look at select case law from the ECtHR demonstrates how the principles of integrity, non-discrimination, and personal autonomy are essential to the establishment of the right to gender identity. The European Convention on Human Rights (ECHR) applies to everyone - including children. The right to respect for one's private life in article 8 includes the right to recognition of one's gender identity, or the

\footnotetext{
${ }^{18}$ Cossey $v$ The United Kingdom, judgment, app no 10843/84, 27 September 1990, dissenting opinion of Judge Martens, [2.7].

${ }^{19}$ Paolo G Carozza, 'Human Dignity' in Dinah Shelton (ed), The Oxford Handbook of International Human Rights Law (Oxford University Press 2013) 346.

${ }^{20}$ See, for example, Universal Declaration of Human Rights (adopted 10 December 1948 UNGA Res 217 A(III) (UDHR) article 1. Convention for the Protection of Human Rights and Fundamental Freedoms (European Convention on Human Rights, as amended) (ECHR) and Convention on the Rights of the Child (adopted 20 November 1989) United Nations, Treaty Series, vol 1577, p 3 (CRC) refer to the UDHR.

${ }^{21}$ Carozza (n 19) 346, 351-356.
} 
freedom to define one's gender. The ECtHR has set forth this right from 2002 onwards. ${ }^{22}$ The principles of autonomy, identity, and integrity are essential features of personal freedom. ${ }^{23}$

The struggle for the right to gender identity, or recognition of one's gender identity, began in $1974^{24}$ when the first case was referred to the European Court of Human Rights. The issue remains unresolved, both at the international and national level. Jill Marshall's analysis of case law from the ECtHR shows that article 8 of the Convention has evolved from a right to respect for one's private life into a right to personal identity. ${ }^{25}$ Michael O’Flaherty says: 'the cases are not about any effort of states to prohibit forms of gender identity choices. Instead, they address the positive obligation on the state to take the administrative actions, such as amendment of identity documents, that are necessary for the affected individuals to live in their changed gender identity. ${ }^{26}$ According to Marshall, the Court has taken a wide and evolving interpretation of ECHR. Its jurisprudence now provides freedom to identityformation and to live as one chooses, as long as it does not harm others. ${ }^{27}$ When ruling in favour of the applicant in the case of Christine Goodwin $v$ the United Kingdom, the Court stated that:

the very essence of the Convention is respect for human dignity and human freedom. Under Article 8 of the Convention in particular, where the notion of personal autonomy is an important principle underlying the interpretation of its guarantees, protection is given to the personal sphere of each individual, including the right to establish details of their identity as individual human beings ... ${ }^{28}$

In addition, the Court finds 'that society may reasonably be expected to tolerate a certain inconvenience to enable individuals to live in dignity and worth in accordance with the sexual identity chosen by them at great personal cost. ${ }^{29}$ The ECtHR concludes that no significant factors of public interest weighed against the applicant's interest in obtaining legal

\footnotetext{
${ }^{22}$ See Christine Goodwin v The United Kingdom, judgment (Grand Chamber), app no 28957/95, 11 July 2002; van Kück v Germany, judgment (Chamber), app no 35968/97, 12 June 2003; Grant v The United Kingdom, judgment (Chamber), app no 32570/03, 23 May 2006; L v Lithuania, judgment (Chamber), app no 27527/03, 11 September 2007; Hämäläinen v Finland, judgment (Grand Chamber), app no 37359/09, 16 July 2014; YY v Turkey, judgment (Chamber), app no 14793/08, 10 March 2015.

${ }^{23}$ Jill Marshall, Personal Freedom Through Human Rights Law?: Autonomy, Identity and Integrity under the European Convention on Human Rights (International Studies in Human Rights, Vol 98 Martinus Nijhoff 2009) 2.

${ }^{24} X v$ The Federal Republic of Germany, app no 6699/74.

${ }^{25}$ Marshall, Personal Freedom Through Human Rights Law? (n 23) 103-122.

${ }^{26}$ Michael O'Flaherty, 'Sexual Orientation and Gender Identity' in Daniel Moeckli, Sangeeta Shah and Sandesh Sivakumaran (eds) International Human Rights Law (Oxford University Press, 2010) 334.

${ }^{27}$ Marshall, Personal Freedom Through Human Rights Law? (n 23) 120-121.

${ }^{28}$ Christine Goodwin (n 22) [90].

${ }^{29}$ Ibid, [91].
} 
recognition of her gender identity. ${ }^{30}$ Similarly, in the case of van Kück v Germany, the Court points out that 'the applicant's freedom to define herself as a female person, [is] one of the most basic essentials of self-determination. ${ }^{31}$ Furthermore, the ECtHR has, in several rulings, addressed the notion that the concept of a private life 'covers the physical and psychological integrity of a person'. ${ }^{32}$ Similarly, the Court relies on the principles of personal development, autonomy, and integrity when finding that the refusal by a Turkish court to authorise gender confirmation treatment for the appellant because he was not permanently unable to procreate, constitutes a violation of article $8 .^{33}$

Even though the ECtHR has stated that 'the prohibition of discrimination under Article 14 of the Convention duly covers questions related to sexual orientation and gender identity', ${ }^{34}$ other human rights bodies have so far addressed the principle of non-discrimination in relation to transgender people more fully than the Court. In 2009, the Committee on Economic, Social and Cultural Rights wrote in General Comment No 20 that 'gender identity is recognized as among the prohibited grounds of discrimination'. ${ }^{35}$ The Committee on the Rights of the Child stresses that '[s]tates parties must address discrimination against vulnerable or marginalized groups of children, such as ... transgender or transsexual ... and make proactive efforts to ensure that such children are assured their right to protection on an equal basis with all other children. ${ }^{36}$ Further, the Committee states that gender identity falls within the scope of 'other status' in article 2 of the Convention on the Rights of the Child. ${ }^{37}$ The UN High Commissioner for Human Rights recommends that states address discrimination by '[e]nsuring that anti-discrimination legislation includes sexual orientation and gender identity among prohibited grounds, and also protects intersex persons from discrimination' ${ }^{38}$

\section{II.iii The legal framework of legal gender assignment at birth and change of legal gender}

\footnotetext{
${ }^{30}$ Ibid, [93].

${ }^{31}$ Van Kück (n 22) [73].

${ }^{32}$ Ibid, [69].

${ }^{33}$ YY (n 22) [122], [102], [57], [65].

${ }^{34}$ Identoba and others v Georgia, judgment (Chamber), app no 73235/12, 12 May 2015 [96].

${ }^{35}$ UN Committee on Economic, Social and Cultural Rights, 'General Comment No 20: Non-discrimination in economic, social and cultural rights’ (2009) UN Doc E/C.12/GC/20 [32].

${ }^{36}$ UN Committee on the Rights of the Child, 'General comment no 13: The right of the child to freedom from all forms of violence’ (2011) UN Doc CRC/C/GC/13 [60], [72 (g)]. For more about the work of the Committee on the Rights of the Child in relation to LGBTI children, see Kirsten Sandberg 'The rights of LGBTI Children and Children with LGBTI Parents under the Convention on the Rights of the Child' in this issue.

${ }^{37}$ Committee on the Rights of the Child, 'General comment no 15: The right of the child to the enjoyment of the highest attainable standard of health (art. 24)’ (2013) UN Doc CRC/C/GC/15 [8].

${ }^{38}$ UNHCR 'Report of the Office of the High Commissioner for Human Rights, Discrimination and Violence Against Individuals Based on their Sexual Orientation and Gender Identity’ (4 May 2015) UN Doc A/HRC/29/23 [79 (c)].
} 
Pursuant to article $7 \mathrm{CRC}$ and article 24(2) of the International Covenant on Civil and Political Rights (ICCPR), every child shall be registered immediately after birth. The registration recognises the child's existence, its status under the law, and ensures the full enjoyment of children's fundamental rights. ${ }^{39}$ The Human Rights Committee (CCPR) states that the main purpose of birth registration is 'to reduce the danger of abduction, sale of or traffic in children, or of other types of treatment that are incompatible with the enjoyment of the rights provided for in the Covenant. ${ }^{40}$ States are under an obligation to make registration compulsory under domestic law to secure its efficiency. The obligation pertains to both parents and the relevant administrative authorities. ${ }^{41}$

In Norway this registration takes the form of the assignment of a mandatory national identity number for all people resident in the country. ${ }^{42}$ The identity number consists of 11 digits, which include the holder's date of birth. The ninth digit differs for legal males and legal females - an even number denotes female and an odd number denotes male. ${ }^{43}$ The number indicates a person's legal gender. The allocation of the national identity number shows that the individual is entered in the legally established Norwegian Population Register. ${ }^{44}$

The Norwegian registration of legal gender is in accordance with the recommendations of the Committee on the Rights of the Child, which identifies sex as one of the basic details that should be registered. ${ }^{45}$ Allocation of national identity numbers is based on the information given - normally by a midwife or a doctor - on the Norwegian birth notification form, which offers the options boy, girl, or unknown. Children who are registered with an unclear gender, are assigned female legal gender. ${ }^{46}$ On the basis of this assignment, all newborns are assigned a gender-specific national identity number once the Norwegian Tax Administration receives the birth notification form. ${ }^{47}$

\footnotetext{
${ }^{39}$ Rachel Hodgkin and Peter Newell, Implementation Handbook for the Convention on the Rights of the Child (United Nation's Children Fund, 2007) 98.

${ }^{40}$ UN Human Rights Committee, General Comment No 17 Rights of the Child (Article 24), (29 September 1989) [7].

${ }^{41}$ Njål Høstmælingen, 'Sivile rettigheter og friheter' in Høstmælingen, Kjørholt and Sandberg (eds), Barnekonvensjonen: Barns Rettigheter i Norge (Universitetsforlaget, 2012) 120.

${ }^{42}$ Act No 01 of 16 January 1970 on the Population Register, 4.

${ }^{43}$ Forskrift om folkeregistrering (FOR-2007-11-09-1268) 2-2.

${ }^{44}$ Act No. 01 of 16 January 1970, 1.

${ }^{45}$ Hodgkin and Newell (n 39) 101.

${ }^{46}$ See form 'Melding om fødsel'; Act No 7 of 8 April 1981 relating to Children s 1; Act No. 64 of 2 July 1999 relating to Health Personnel etc, 35. Email to the author from Harald Hammer in the Norwegian Tax Administration 1 April 2015.

${ }^{47}$ FOR-2007-11-09-1268, 3-1.
} 
Through the allocation of a national identity number, all individuals are categorised at an early stage of life within the binary gender model. One's legal existence begins with this number, and ends with the entry of the identity number in the death register. However, pursuant to Norwegian administrative regulations dating back to 1979, the possibility to change legal gender exists. The national identity number can be changed if 'gender status' is changed. ${ }^{48}$ The term 'gender status' is defined by neither law, preparatory work, nor other sources of law. ${ }^{49}$ Yet, according to administrative practice, change of legal gender requires complete gender confirmation treatment. Change of legal gender, which is administered by the Norwegian Tax Administration, requires the diagnosis of F64.0 transsexualism, real-life experience of at least twelve months' duration, hormone treatment, and surgical removal of testis or ovaries. During the period of real life experience, transgender people are required to live full-time as their preferred gender. In 2014, 500 people were registered as patients at the National Treatment Unit for Transsexualism - among them 110 children. The implicit age limit for change of legal gender is 18 years, given the surgical requirement. The old national identity number is kept in the national population register after the new one has been allocated. The old number refers to the new number and vice versa. ${ }^{50}$

Norwegian administrative practice on legal gender recognition is problematic in relation to numerous human rights. In 2013 the UN Special Rapporteur on Torture stated that interventions such as the involuntary sterilisation of transgender people, 'always amount at least to inhuman and degrading treatment ... and they are always prohibited by international law. ${ }^{51}$ To enjoy legal recognition in accordance with one's gender identity falls within the core provision of article $8 .^{52}$ To be excluded from legal gender recognition because one fails to fulfil the medical requirements, or to be compelled to undergo surgery one does not desire, encroach on this right. As several domestic courts have concluded, medical requirements violate the right to respect one's private life and physical integrity. In 2011, the German Constitutional Court ruled that gender reassignment surgery is in breach of the right to selfdetermination and physical integrity. ${ }^{53}$ Similarly, in 2012, the Swedish Administrative Court of Appeal in Stockholm ruled that the Swedish sterilisation requirement constituted a forcible

\footnotetext{
48 Forskrifter om Føringen og Ordningen av Folkeregistrene (FOR-1979-11-26-9) 58; Forskrift om Folkeregistrering (FOR-1994-03-04-161) s 31; Forskrift om Folkeregistrering (FOR-2007-11-09-1268) 2-2.

${ }^{49}$ For a discussion of the legal basis of the requirements, see Anniken Sørlie, 'Retten til kjønnsidentitet som menneskerettighet: Kan norsk forvaltningspraksis' krav om irreversible sterilisering ved endring av fødselsnummer forsvares?' (Kvinnerettslig skriftserie nr 902013 University of Oslo).

${ }^{50}$ The Norwegian Directorate of Health, 'Rett til rett kjønn - Helse til alle kjønn: Utredning av vilkår for endring av juridisk kjønn og organisering av helsetjenester for personer som opplever kjønnsinkongruens og kjønnsdysfori' (2015) 36, 43-47, 54, 65.

${ }^{51}$ UNGA 'Report of the Special Rapporteur on torture and other cruel, inhuman or degrading treatment or punishment, Juan E Méndez’ (1 February 2013) UN Doc A/HRC/22/53 [81], [76].

${ }^{52}$ See part II.ii

${ }^{53}$ Federal Constitutional Court, 1 BvR 3295/07.
} 
intrusion into an individual's physical integrity. ${ }^{54}$ The interference cannot be justified in light of article 8(2). In addition, as regards the Norwegian case, the practice lacks sufficient legal basis to justify interference with the right to respect for one's private life. ${ }^{55}$

As mentioned in the introduction, to bring Norwegian administrative practice in line with the human rights obligations of the Norwegian state, the legal proposal suggests that a change in legal gender shall be done without medical interventions or diagnoses. Instead, a feeling of belonging to a gender different from that assigned at birth is required. The only 'proof' of this is by self-declaration. The proposal thus suggests that children should be able to change their legal gender. Children over the age of 16 could demand to change their legal gender independently, whereas children between the ages of seven and 16 could demand legal gender change if parental consent is gained. ${ }^{56}$ The proposal demonstrates one of the many different ways in which to implement the human rights of transgender people. The different alternatives ensure the fundamental principles of autonomy, dignity, integrity, and nondiscrimination for all human beings to varying extents. Drawing on the analysis in section IV, I discuss alternative ways of incorporating human rights principles into Norwegian law in section $\mathrm{V}$.

\section{Linking Ethical, Legal, and Empirical Dimensions}

As already mentioned, Professor Tove Stang Dahl has provided three main methodological sources for the study of the relationship between gender and law: the ethical, the empirical, and the doctrinal. ${ }^{57}$ This approach, which takes the lived realities of women as the starting point for examinations of the relationship between gender-neutral law and gendered realities, has inspired me to give voice to vulnerable individuals at the cutting edge of this dilemma, in being both children and gender non-conforming. To this end, I have conducted interviews with young transgender people and their parents.

\section{III.i Qualitative interviews, case studies, and legal story telling}

For the purposes of my PhD project, I carried out ten interviews with transgender people or their parents. ${ }^{58}$ The interviews form part of a larger qualitative multiple-case study. Robert $\mathrm{K}$

\footnotetext{
${ }^{54}$ Mål nr. 1968-12, Kammarrätten i Stockholm, Avdeling 03.

${ }^{55}$ For an evaluation of the requirement for irreversible sterilisation in Norway, see Anniken Sørlie, 'Tvungen identitet - en vurdering av norsk forvaltningspraksis' krav om irreversibel sterilisering ved endring av juridisk kjønn’ (2014) 12(4) Tidsskrift for familierett, arverett og barnevernrettslige spørsmål 272. See also Sørlie, 'Retten til kjønnsidentitet som menneskerettighet' (n 49).

56 The Ministry of Health and Care Services (n 7) 2 and 4 of the proposal.

${ }^{57}$ Stang Dahl (n 10) 61.

${ }^{58}$ I obtained approval from the National Social Science Data Services (NSD) before I started the data collection. In addition, I applied for a project in TSD (tjeneste for sikker datalagring) before carrying out the interviews in
} 
Yin defines case study as 'an empirical inquiry that investigates a contemporary phenomenon (the "case") in depth and within its real-world context, especially when the boundaries between phenomenon and context may not be clearly evident. ${ }^{59}$ The case study design was chosen because it facilitates further analysis of the relationship between legal gender and recognition and misrecognition of gender non-conforming children and adolescents. The selection of different cases makes it possible to evaluate the broad phenomenon of legal gender and the relation between law and transgender people, by taking different approaches and perspectives. This approach demonstrates the complexity and paradoxes arising from legal gender as regards transgender people.

Three particular interviews are used in this article because the children involved started to live in accordance with their gender identity as young children and can therefore provide information about their experiences as children, which is the focus of this article. These stories also provide information about parents' experiences. The narratives of two mothers, one father, one child, and one young man form the basis of the three stories about young lives told in this article: the struggles of Paul, Christine, and Daniel for recognition. Paul, Christine, and Daniel live in different cities in Norway and have lived in accordance with their gender identity for at least six months. Paul and Christine are between six and ten years old, whereas Daniel is over the age of majority. They have changed their first names so that they correspond with their gender identity in the national population register. Though they wanted their legal gender to match their gender identity, the gender designated at birth is still listed as their legal gender. They are anxious for a change in Norwegian practice. Paul, Christine, and Daniel have been in contact with their general practitioners and the children's and young people's psychiatric out-patient clinic (BUP) because of their gender incongruence. According to Paul's mother, Paul identifies as a boy and as a transgender person. He has started taking puberty-blockers prescribed by his general practitioner. Christine identifies as a girl, and she also defines herself as a transgender person. Daniel identifies as a boy and is undergoing gender confirmation treatment at the National Treatment Unit for Transsexualism, but he says that he does not identify as transsexual. He has started hormone treatment, but apart from that will do as little as possible to his body.

Narrative methods are particularly useful when working with cases. These methods draw attention to why and how a story is told and the social and local context of the stories comes to the fore. ${ }^{60}$ Professors Daniel A Farber and Suzanna Sherry point out that: 'legal storytelling ... usually focuses on the narrator's experience of events. Stories supply both the

\footnotetext{
order to ensure the secure storage of information about my informants which could directly or indirectly identified them.

${ }^{59}$ Robert K Yin, Case Study Research: Design and Methods (5th edn, Sage 2014) 16.

${ }^{60}$ Catherine Kohler Riessman, Narrative Methods for the Human Sciences (Sage, 2008) 12-13.
} 
individualized context and the emotional aspect missing from most legal scholarship. Thus "personal narrative” is described as a "feminist method.", 61 John Paley and Eva Gail hold that '[a] "narrative” refers to the sequence of events and the (claimed) causal connection between them. ${ }^{62}$ While a story has a plot and character, this is not true of all narratives. Every story is a narrative, but not all narratives are stories as they may lack the organisational structure of a story. ${ }^{63}$ As Catherine Kohler Riessman puts it, narratives invite readers 'to enter the perspective of the narrator. ${ }^{64}$ At the same time, the truth of narratives can be questioned. Narrators choose which stories to tell, and by so doing, construct their preferred narratives about themselves. The presence of the researcher, listening and asking questions, also influences what narrators choose to tell, and the researcher thus takes part in the construction of the narrative. ${ }^{65}$ In this study, in the case of two of the stories, the narrator was a parent, not the gender non-conforming person himself/herself, which has a bearing on the analysis. In addition, I decided which stories to analyse in this article. The analysis may differ from the informant's own interpretation of the event. The consents from my informants do not include my analysis of their narratives, since the analysis has developed in the course of the project. It is important to bear in mind that my analysis is an alternative way of interpreting the informants' narratives, based on the approach taken in this article. ${ }^{66}$

The theory of recognition serves as a tool for interpreting the narratives. The narratives are categorised and analysed thematically under the three different spheres of recognition: (1) the legal sphere, (2) the private sphere, and (3) the social or solidarity sphere, following Honneth's theory of recognition. Each sphere presents different narratives: coming out to family and coming out to friends, awareness of legal gender and its impact on everyday life, and living openly in a binary society. Though my analysis focuses on content, or what the narrator describes, the analysis also takes note of the societal context in which the narratives emerge.

The narrative approach within this field where biases and transphobia are widespread can help increase knowledge about the role of law within society, and describe and discuss gender non-

\footnotetext{
${ }^{61}$ Daniel A Farber and Suzanna Sherry, ‘Telling Stories Out of School: An Essay on Legal Narratives’ (1993) 45 (4) Stan L Rev 807, 811.

${ }^{62}$ John Paley and Gail Eva, 'Narrative Vigilance: the Analysis of Stories in Health Care' (2005) 6 Nursing Philosophy 83, 83 quoted in Yasmin Gunaratnam and David Oliviere (eds), Narrative and Stories in Health Care: Illness, Dying, and Bereavement (Oxford University Press, 2009) 2.

${ }^{63}$ Gunaratnam and Oliviere (n 62) 2.

${ }^{64}$ Kohler Riessman (n 60) 9.

65 Ibid, 7, 9, 50.

${ }^{66}$ Tove Thagaard, Systematikk og innlevelse: En innføring i kvalitativ metode (4th edn, Fagbokforlaget Vigmostad \& Bjørke AS, 2013) 132-133.
} 
conforming children's position in law and society. ${ }^{67}$ It says something about the narrator's experience of an event, and the narrators' narratives give information about the norms and culture in which the experiences originate. ${ }^{68}$ In this way, the narratives can provide information about structures that might otherwise be difficult to unearth.

\section{III.ii Data collection}

In order to get in contact with potential informants, and at the same time ensure that they did not feel pressured to participate, I contacted the following Norwegian organisations, together with a few key people: the Harry Benjamin Resource Centre, the National Association for Lesbians, Gays, Bisexuals and Transgender Persons (LLH), Queer World, the Association for Transgender People and Stensveen Resource Centre. They circulated my information letter and request for participants to their members and contacted people they thought might be interested in taking part. Anyone interested in participating was asked to contact me either directly, or, if they did not want me to know their identity, through the person who contacted. My involvement in the LGBT movement, both as an activist and as a researcher, could have made potential informants feel pressured to participate. This strategy, however, ensured that participants consented freely, which was crucial for my chosen recruitment method.

Amongst those who responded, I selected 10 families or individuals with different gender identities, of different ages and ethnicities, in order to ensure as much diversity amongst the informants as the response allowed. The youngest informant is between six and 10 years old, and the oldest between 70 and 80. Asking potential informants to contact me might have led to a bias, in the sense that my informants might be more comfortable speaking about their life than would be the case for transgender people in general. However, the interviews revealed differences between the informants, though they all hoped that their participation would contribute to a better life for transgender people in Norway. In that respect, their participation was based more or less on a sort of activist agenda.

The interviews used in this article were conducted in 2015. The informants were interviewed face to face, at a place of their choosing. Beforehand, every informant received an information letter in which the project was explained. Before starting the interview, I provided further information about the project and encouraged the informant to ask questions. Each informant gave written consent. In addition to interviewing Christine's parents, I had a short conversation with Christine, whose mother consented on her behalf. She was informed about the project before we met, and her mother took part in our conversation. The main part of Christine's story is based on the interviews with her parents, but during my conversation with her she confirmed her parents' narrative, when her mother referred to things they had said.

\footnotetext{
${ }^{67}$ See Norman Anderssen and Kirsti Malterud (eds), Seksuell orientering og levekår (Uni Helse/Uni Research, 2013) on, inter alia, attitudes towards transgender persons in Norway.

${ }^{68}$ Thagaard (n 66) 152-155.
} 
The interviews were semi-structured. Each informant was invited to speak freely on matters such as identity, coming out, feelings of recognition, school, meetings with health care institutions, legal gender, legal name, and positive and negative experiences in different situations. Follow-up questions were asked to a varying degree, depending on the specific conversation. The interviews lasted from around one hour to up to four hours, and were recorded on two devices: a smart phone and a Dictaphone. After the interviews, I transcribed the data and deleted the audio files to ensure that any information which could be used either directly or indirectly to identify the informant or their child was destroyed.

\section{The Struggle for Recognition}

'[E]very individual is dependent on the possibility of constant reassurance by the Other; the experience of disrespect poses the risk of an injury that can cause the identity of the entire person to collapse. ${ }^{, 69}$

In this part, I present the narratives and analyse them in the light of Honneth's theory of recognition. First, I introduce and analyse the narratives I have categorised as being within the private sphere. Secondly, I turn to the legal sphere, before going on to present the narratives relating to the social sphere.

The informants used many of the same terms, such as acceptance, normal, self-confidence, to shield, the state, the system, vulnerability, role models, fear, to protect, and to feel safe. At the same time, one word can describe and summarise their narratives: strategy. In each sphere of recognition, the informants tell stories about how they or their children navigate amongst binary gender norms and prejudices and develop strategies to deal with them. Their strategies concern, inter alia, coming out, building self-confidence, dealing with negative attitudes, and confronting lack of resources, and unwillingness to change structures at school. The parents describe feeling of constantly fighting the system, feelings of inadequacy, and how they must contend with negative attitudes and the fear of doing something wrong. The narratives portray structural disadvantages and binary gender norms, which challenge their everyday life.

\section{IV.i The first step towards recognition: The fear and strategies involved in coming out in the private sphere}

The first pattern of recognition, love in the private sphere, is the first step towards selfrealisation. By love, Honneth means a strong emotional connection between a few people,

\footnotetext{
${ }^{69}$ Axel Honneth, 'Integrity and Disrespect: Principles of a Conception of Morality Based on the Theory of Recognition’ (1992) 20(2) Political Theory 187, 189.
} 
such as parents and children, or strong friendship. The experience of mutual recognition makes individuals realise that they are dependent upon each other. ${ }^{70}$ In this part, I focus on the child-parent relationship and on relationships with other family members. Coming out is not a one-off experience. For the purposes of presenting the narratives, I identify the coming out experience as having two main parts for the youngest informants: the child's coming out to the parents, and the next step: the shared coming out of the child and parent.

\section{Gender spectrum}

Before I present the coming out stories, some background on the parents' conception of gender is useful. Christine and Paul's mothers describe their children's childhood as genderneutral. According to them, their children were free to choose their toys and to wear whatever clothes they liked. The mothers recall that they did not pay much attention to this. This is in tune with their conception of gender. Christine's mother says: 'It's not just men and women and transgender. It's a great human spectrum.' This quote also illustrates Paul's mother's view of gender. In addition, she emphasises that gender and its variations can change throughout life. This implies that they situate themselves within a post-structural understanding of gender.

\section{Aloofness - I didn't know anything about it}

Nevertheless, Christine and Paul had to come out to their parents - an experience their parents describe as difficult, both for their child and for themselves. The process can be described as involving uncertainty, lack of knowledge, anguish, and a situation where one's child takes the lead - either coming out to the parents or when coming out at school. The childhoods of Christine and Paul, which had been free from gender stereotypes, suddenly changed. Their freedom was restricted. Christine's parents limited her gender expression, and both Paul and Christine's parents were reluctant to their expressed wish to live in accordance with their gender identity. Though the parents describe themselves as pro-gender neutrality and gender fluidity, it would appear that society's gender norms and prejudices were of great concern to them at the beginning of their child's coming out process.

Coming out to parents is narrated as being a lengthy process, which started with hints that eventually led to an explicit expression of the need to live as a girl or a boy. Paul's mother says:

I tried to say the right things, such as you [Paul] know that we will always love you and you know that it is possible to do something about it [your body] when you get older... [I said this] given my limited knowledge at the time, I did not know and had not heard that such small children [could experience

\footnotetext{
${ }^{70}$ Honneth, Kamp om anerkjennelse (n 14) 104.
} 
this]... So, we decided to delay [the transition] until later. I believe that he took this as a bit of a rejection, even though, formally, it was an acceptance [from me].

The Norwegian TV series 'Born in the wrong body ${ }^{\text {,1 }}$ was the trigger for Paul's coming out to the rest of his family. Paul had already made his parents aware of his gender identity, but everything had been put on hold due to his parents' uncertainty. Then Paul used the series to illustrate what his life was like. When his mother asked him why he was unhappy, he was able to refer to the series without needing to elaborate. The programme thus provided Paul with a language and his parents with knowledge. From then on he started to live openly as a boy. His parents told his family, school, and local community.

The two mothers spontaneously speak of their subsequent regrets. It appears evident to me that the way they reacted to their child's coming out causes them great unhappiness. Christine's mother recalls: 'It wasn't nice of me, but I did it because I thought it was healthier for her. ... Afterwards I've felt very ashamed.' Paul's mother says: 'In retrospect, I've regretted that I took so long and postponed it. At the same time, I think that if I'd just immediately said "of course", then maybe later I would have been asking myself whether I pushed him.'

Both children told their parents relatively early in life. Coming out to other family members, however, took some time - for one thing, because the children needed time to develop a language to 'convince' their parents, and their parents needed to get information about the matter. In both cases, coming out to grandparents, aunts and uncles, etc is described as a pretty smooth process. Most family members accepted the child's wish, but both families have broken contact with a few family members who harbour negative attitudes against the child's transition so as to shield their child.

Christine took charge of her own coming out to her friends and the local community by wearing dresses and asking her friends to call her Christine from then on. She recalls that she was a bit surprised because no one actually seemed to care, but she says that now and then children ask her about the clothes she is wearing and whether she is a girl or a boy. At home her parents try to give her as much reassurance as possible to help her handle these situations.

According to Paul's mother, he changed a lot after he started to live openly as Paul. She describes it as 'getting [her] child back,' but the positive changes lasted only a short time. School children soon started to use the wrong pronoun and some parents complained to the school. 'It goes against my faith', one parent said.

\footnotetext{
${ }^{71}$ A Norwegian documentary of six episodes directed by Petter Vennerød broadcast on TV2 in 2014. It follows 14 people and their experiences during the process of gender confirmation.
} 


\section{I want to be a boy in my next life because I can't be a boy now}

Daniel used to think that he could not live as a boy in this life, but might do so in another. After many years he came to the following conclusion:

I felt that either I had to receive my new life now or I had to create something of it myself, if you understand what I mean. Either I have to end it, be over and done with it, or I had to face it straight on and be honest about what it was and try to find help... The hate [that I had] became greater and greater and I became even more tired. It was a vicious circle; it felt really good to be honest and to see that things got better.

Unlike the two mothers, Daniel does not speak of a trigger, but of an ever-increasing struggle to live. The question about whether to be open turned into a life-and-death matter. He speaks self-confidently about it without directly saying that he was contemplating suicide. His suffering is similarly implied in many of his narratives, without being directly expressed. As mentioned in the introduction, Daniel experiences recognition and support from his mother, but misrecognition from his father. While he openly speaks about coming out to his mother, it is only in response to my question that he discusses coming out to his father:

\footnotetext{
I just think it's so comical. ... I said, 'please, don't hate me, I want to feel good'. And he responded, 'no, no, but you are my child.' Then I became so happy and I thought that he had accepted and understood me. Then, two months later, he says, sorry, but you will always be my little girl and my little princess. ... Since then, I have tried to talk to him about this on a regular basis, but I don't believe he is capable of understanding it, so I just stopped going over there [to his house]. I'll go back [over there] when I have a beard and then we can see who the little princess is.
}

Before telling his parents, Daniel told some of his friends. He describes this as a trifling, and says that this revealed a lot about himself as a person to his friends.

Fear is a feature of the coming-out narratives. Daniel expresses his own fear, whereas the two mothers' narratives express parents' fears towards the attitudes that their child will meet in everyday life. In subsection IV.iii, which deals with the social sphere, I explore further how the informants strategically try to avoid or deal with these attitudes, and will also relate their fears to surveys on transgender peoples’ quality of life.

The importance of participation and recognition in the private sphere is illustrated by Daniel's fear of coming out, and the mothers' description of how their children changed when they and other people accepted them. This change in their self-confidence squares well with Honneth's emphasis on this sphere as a determinant of identity formation. When children feel confident about their parents' love, they will develop a self-confidence that enables them to be alone 
and independent. ${ }^{72}$ In the case of the informants, they are made capable of facing society and other people, thanks to their devoted parents and their unconditional love. A parent's acceptance of a gender non-conforming child, and the fact that the parent regards transgender and gender fluidity as normal and something positive, are great demonstrations of parental love. The development of self-confidence is, according to Honneth, the psychological condition for the development of any other kind of self-relation or form of recognition. ${ }^{73}$ As children, without the support of their legal guardians, who in most cases are their parents, they exhibit a limited ability to enjoy their rights. In this way, Honneth's ontogenetic 'stairway' to recognition matches children's steps towards recognition. The next subsection looks at the legal sphere and demonstrates how children have no access to recognition without the support of parents.

\section{IV.ii The legal sphere}

Many think that such a record [birth record] is needed to comply with a person's human rights to know who they are. This implies that who they are exists at birth. ${ }^{74}$

As demonstrated above, human rights, as well as domestic law, form and create subjects of law through legal provisions regarding legal gender assignment at birth and legal gender recognition. To be excluded from the legal system, in the sense of being excluded from certain rights, can impact on a person's psychology and on how one perceives one's identity. ${ }^{75}$ Several scholars have criticised the role of medicine in determining what, for legal purposes, gender is. Julia Greenberg, among others, stresses that 'the legal community must question its long-held assumptions about the legal definitions of sex, gender, male, and female. ${ }^{76}$ Depending on how laws and regulations are applied in reality, laws can create a set of norms which clearly define the gender borders of a society. Existing Norwegian legislation requires early assignment to either male or female legal gender on the basis of a medical conception of gender. For legal gender to be changed later in life, there has to be an absence of reproductive organs. This constitutes biological determinism and the construction of a dualistic gender regime within the legal system. ${ }^{77}$

\footnotetext{
${ }^{72}$ Honneth, Kamp om anerkjennelse (n 14) 113.

73 Ibid, 116.

${ }^{74}$ Marshall, Human Rights Law and Personal Identity (n 9) 7.

${ }^{75}$ Ibid, 12.

${ }^{76}$ Julie A Greenberg, Intersexuality and the Law: Why Sex Matters (New York University Press, 2012) 292.

${ }^{77}$ See subsection II.iii.
} 
Transgender children and adolescents are protected against discrimination on the grounds of gender identity and gender expression. ${ }^{78}$ In this regard, they are entitled to the same protection as everyone else when it comes to matters of gender identity and gender expression. According to Norwegian law, children who have their parents' permission have the right to change their legal name. ${ }^{79}$ The change is supposed to require only the individual's own statement that he or she belongs to a different gender, or is transgender, but the administrative circular letter is unclear when it comes to children. ${ }^{80}$ Change of legal gender on the other hand, is open only to a small number of people in Norway - and definitely not to children. ${ }^{81}$

What experiences of legal gender do gender non-conforming children and adolescents - or their parents - narrate, and what can we generalise from these narratives? The narratives are reported and analysed in the context of existing Norwegian administrative practice. Does legal gender matter and if so, in what way? Does it impact on young people's feelings of selfrespect and recognition?

\section{Change of legal gender - 'we will do everything we can to show our support'}

Daniel, Paul, and Christine live with a legal gender that does not match their gender identity, but their knowledge of their legal gender varies. Daniel became aware of his legal gender as a teenager, whereas Paul is still ignorant of his. Christine, on the other hand, is fully aware of the information given by national identity numbers. However, she does not know that her passport has a separate gender marker, in addition to carrying her national identity number.

Christine and Paul's mothers would have changed their child's legal gender if the age restriction were lower and if no surgery or other medical interventions were required. However, they regard the change of name as more important to their children. Christine's mother says: 'Her name has been very important to her. I don't think it [the legal gender] matters to her because she's so young. She doesn't understand the significance of it.' At the same time, Christine has been very focused on undergoing gender reassignment surgery. Her mother says: '[w]e're wondering if [Christine] would have changed the way she's thinking because she's very focused on surgery ... because the state requires that to let her be a woman.' Christine and Paul's mothers speak of changing legal gender and legal names as proof of their support and respect for their children. This is thus a part of the child/parent relation and an expression of the parents' love for their child, which is necessary for the

\footnotetext{
${ }^{78}$ Act No 58 of 21 June 2013 prohibiting discrimination on the grounds of sexual orientation, gender identity and gender expression s 5. See also subsection II.3.

${ }^{79}$ Act No 19 of 7 June 2002 on names s 12.

${ }^{80}$ Administrative circular on names of 15 November 2002 (G-2002-20).

${ }^{81}$ See subsection II.ii.
} 
child's enjoyment of his or her rights. Changing their name was possible for Paul, Christine, and Daniel because they had supportive parents. ${ }^{82}$

The discrepancy between the rules regarding change of name and change of legal gender enables children to obtain partial recognition of their identity in the legal sphere. They are thus not able to obtain the greatest possible self-respect. In addition, they are dependent upon recognition in the private sphere to develop any form of self-respect. This creates young identities which do not match with their legal gender and gendered legal names. It leads to a risk that their gender history will be disclosed in public situations like travelling.

The liberal narratives on legal changes coincide with the two mothers' view of gender presented above. Paul and Christine's mothers present their children, rather than themselves, as experts on their own identities and oppose medical authority. By letting their children decide, and by regarding as insignificant the possibility of a future change back, they break away from the biological, dualistic gender regime embedded in medicine, law, and Norwegian society. They thus situate themselves within the more theoretical conception of gender as being social and historically constructed.

\section{The power of the Norwegian state - the creation of abnormal citizens}

The formation of a person's identity takes place within a social context, which is determined, among other things, by the capacity for choice provided by law and legal regulations. The narratives speak of the repressive effect of Norwegian law. The informants emphasise state authority and express anger towards the system. Even though I did not ask any direct questions about the medical requirements for changing legal gender, their narratives on legal gender centre around the requirement of sterilisation and the power of the Norwegian state and the National Treatment Unit for Transsexualism. They describe current practice as an assault, shameful, incomprehensible, and unfair.

Daniel felt marked when he realised that he had a legal gender. He says: 'the state has told me who I am the whole time and I didn't even know.' He elaborates on the medical requirements:

I don't want the state to take my reproductive organs because they should be there and because, as I said, it's my body and I have to figure out how to live with it. This upsets me a lot, especially when I think about how they [the state] want to take away my ability to have kids. As if I'm something abnormal, an abnormal human being who has special needs. I'm not. I just want to live like everyone else.

\footnotetext{
${ }^{82}$ Act No 19 of 7 June 2002 s 12.
} 
Daniel's narrative - as well as those of the mothers - sees the requirements as symbols of their 'abnormality' - or society's judgement of normality. They make transgender people 'the other', or as Alex Sharpe puts it, monsters. ${ }^{83}$ Their narratives clearly demonstrate that they feel that the state treats them differently and values them less than other citizens because of the requirements. Drawing on Marshall, we can see this as an example of how law excludes identities, on the basis of social norms. The feeling of being 'the other' or of less value due to lack of rights, weakens the feeling of self-respect, according to Honneth. ${ }^{84}$ Both the fact that they lack the right to change legal gender, and the requirements currently needing to be satisfied before change can take place, hinder the development of self-respect. Birth registration, that was supposed to ensure their rights, results in the erosion of their dignity and integrity. They are not free to shape their identity, and this interferes with their right to personal identity. They are not treated the same way as cisgender ${ }^{85}$ people in Norway since cisgender people's gender identity has full legal recognition without any requirements as to what their body should look like, or whether or not they are able to procreate. ${ }^{86}$ Yet, in the case of transgender people, their bodies are strictly controlled if they are to acquire a legal gender different from the one they were assigned at birth.

In a modern society, transgender people should anticipate the same treatment as cisgender people and to have dignity and rights. Structural denial of legitimate expectations of equal rights leads to a feeling of disrespect. According to Honneth: 'the person is deprived of that form of recognition that takes the shape of cognitive respect for moral accountability.' Being denied rights may lead to loss of self-respect and self-esteem. ${ }^{87}$ Discrimination against whole groups of people is an example of disrespect that can influence or damage our self-respect. ${ }^{88}$

\section{IV.iii The social sphere}

Heteronormative dominance can result in suppression of one's gender identity and therefore hinder positive development or formation of identity. This lack of support in the social

\footnotetext{
${ }^{83}$ A Sharpe, Foucault's Monsters and the Challenge of Law (Routledge 2010).

${ }^{84}$ Honneth, 'Integrity and Disrespect' (n 69) 190-191.

${ }^{85}$ Cisgender refers to people whose experience of their gender align with the gender they were designated at birth.

${ }^{86}$ In 2014, the Norwegian Equality and Anti-Discrimination Ombudsman decided that the Ministry of Health and Care Services had discriminated against the appellant - a woman whose birth-designated gender was male - when she was refused to change her legal gender because she did not meet the medical requirements. Case 14/840, 9 September 2014.

${ }^{87}$ Honneth, 'Integrity and Disrespect' (n 69) 190-191.

${ }^{88}$ Mogens Chrom Jacobsen (trs), 'Mellem Aristoteles og kant: En Skitse til Anerkendelsens Moral' in Axel Honneth: Behovet for Anerkendelse: En Tekstsamling (Mogens Chrom Jacobsen (trs) and Rasmus Willig (ed), Hans Reitzels Forlag 2003) 88.
} 
context can lead to poor mental and social health. ${ }^{89}$ According to Honneth, self-realisation presupposes social value - or self-esteem. As self-confidence and self-respect presuppose intersubjective relations, this form of recognition presupposes an intersubjective horizon of values. Individuals can only value each other if they share values, which is a sign that their qualities matter or contribute to the other person's life. The conditions for the social value of individuals are, however, determined by society's cultural self-realisation. The social value of qualities and skills are rendered concrete by cultural interpretations. Honneth considers as very significant the role interest organisations play in the struggle to ensure that certain groups are valued more highly, but he points out that the struggle for social value is a permanent fight. ${ }^{90}$ It is exactly this constant fight for acceptance that the informants narrate.

\section{The transparency of identity documents versus passing - like winning a marathon}

I hold my breath when I show it [my bank card] because I think that everyone understands what the third from last digit means, because I know what it means, and so I think that everyone else knows it as well. What if they see it? ${ }^{91}$

Exclusion from rights can expose transgender people to harassment and fear. The informants point to passports and other identity documents as especially problematic because their legal gender is revealed in those documents and they cannot be changed. They feel that the passport explicitly discloses their own or their child's gender history, and that it is impossible to hide this information from strangers. Daniel says:

I think it's a shame to get that knowing look when I show [them] my passport. ... It's a very unpleasant reminder. It's not simply an innocent three-year-old photo ... it does hurt to see it. Although the sex of my reproductive organs is not written on my face, it is in my passport. I don't think this is cool. And everyone can see it. Everyone who sees my passport can see it as well. I might as well just be stripped naked.

Daniel compares the information on his passport to being naked. It exposes intimate information and puts him in situations of indignity and insecurity. He expects to experience non-passing. Daniel explains his fear of non-passing:

I usually think it's okay to go to the men's loo. I don't usually think about it, but then I get these waves of dysphoria. I don't have dysphoria constantly, it just comes in waves and then it gets bad, bad, bad. And then it gets better. But when a wave comes and I have to go to the loo, then I feel as though

\footnotetext{
${ }^{89}$ Sam Larsson and others, 'Vem får man vara i vårt samhälle? Om transpersoners psykosociala situation och psykiska hälsa' (Statens folkhälsoinstitut, 2008) 236-237.

${ }^{90}$ Honneth, Kamp om anerkjennelse (n 14) 130-138.

${ }^{91}$ Daniel.
} 
everyone is looking at me and that, in their eyes, I don't belong there. Will I be beaten up now? I want to go home. Or to sit there with the door locked until I hear that everyone has left, and then run out.

In these situations he tries to focus on all the times he has experienced passing, when he had not expected to. Daniel describes the feeling of passing like this:

I don't think there are words to adequately describe this [feeling]. I have found the meaning of life and the happiness that comes with having found this meaning... It's as though I've run a marathon that I never thought I would manage to finish and I have finished in first place.

Anthropologist Jason Cromwell writes:

Within transsexual discourses, passing means blending in and becoming unnoticeable and unremarkable as either a man or a woman. Blending in as normal means that one has succeeded and become a 'real' man or woman. With 'realness' an individual is no longer a member of the stigmatized group of transsexuals; she or he has completed ‘transition’ and is now ‘just a woman’ or ‘just a man.' 92

The narratives from Paul and Christine's mothers tell the story of children who mostly pass in accordance with their gender identity. Yet, their narratives show that the children are tremendously afraid of their gender history being disclosed and feel that their bodies are their greatest enemy in this regard. Swimming is singled out as the most challenging issue, and is something Paul and Christine try to avoid. They feel exposed. Christine’s father talks about an experience at the beach:

It took her an hour and a half - two hours before we managed get her changed. ... While you would have been running around naked without thinking about putting on your swimming costume, she couldn't take off her clothes. She had to build a house with a fence around it and two safety guards outside in order to change her clothes. ... But there is nothing. Nobody can see it. There's not much difference between [girls’ and boys' bodies at that age]. ${ }^{93}$

Zowie Davy criticises Thomas Kando in his suggestion that passing is impossible in relation to people who knew the transsexual before transitioning. According to Davy, whether a transsexual person passes or not depends on the person who is passing their opinion, and on the transsexual's bodily aesthetic. ${ }^{94}$ The narratives imply that Paul, Christine, and Daniel regard their bodies as markers of their difference from cisgender people and as symbols of their trans identity.

\footnotetext{
92 Jason Cromwell, Transmen and FTMs: Identities, Bodies, Genders and Sexualities, (University of Illinois Press, 1999) 39.

${ }^{93}$ Rewritten to protect anonymity.

${ }^{94}$ Zowie Davy, Recognizing Transsexuals: Personal, Political and Medicolegal Embodyment (Ashgate, 2011) 59.
} 
The children's fear of non-passing can be interpreted as meaning that they do not expect to pass and that they expect other people to think that they - because of their bodies - break Norwegian norms. They fear to be discovered and feel that other people regard them as 'less worthy'. Passing, on the other hand, releases them from their fear of being devalued and of being subjected to transphobia. It increases their self-esteem.

\section{Construction of a self within a social and legal construction of abnormality}

I think I would get by just fine on an island by myself. I would be able to come to terms with this in a very different way versus when people are around me. I do not believe that I am cause of my shame. Rather, other people are the cause of this. ${ }^{95}$

In a Norwegian inquiry of 2013, a minority of respondents reported negative attitudes to transgender people (men 20 per cent, women 9 per cent). ${ }^{96}$ Amongst the male respondents, 49 per cent supported the statement that human variation is a good thing, such that there are women, men, transgender, and other people, whereas 65 per cent of the female respondents supported this statement. ${ }^{97}$ However, 55 per cent of the male respondents and 52 per cent of the female respondents expressed negative attitudes towards the kissing in public by people who do not fit within the two gender categories. ${ }^{98}$ Though a minority of respondents expressed negative attitudes towards transgender people, the survey shows that prejudice against transgender people is present in Norwegian society.

Alex Sharpe demonstrates that cisnormativity and transphobia are embedded in law and society by discussing criminal cases where transgender men are convicted for sexual offences because they do not disclose their gender history to their female cisgender partner prior to sexual intimacy. ${ }^{99}$ These cases are good examples of damaging prejudice transgender people may face in society and how the legal system is not free from prejudice, cisnormativity, or transphobia. Social values are not detached from law. The law embodies social values that impact our identities. ${ }^{100}$ Norwegian administrative practice regarding legal gender recognition is an example of this.

According to the mothers, their children express unhappiness at being born the way they were. Christine’s mother recalls Christine asking: ‘Mum, why wasn’t I just born a girl? Can I

\footnotetext{
${ }^{95}$ Daniel.

${ }^{96}$ Anderssen and Malterud (eds) (n 67) 130-131.

${ }^{97}$ Ibid, 135.

${ }^{98}$ Ibid, 136.

${ }^{99}$ Alex Sharpe. 'Sexual Intimacy, Gender variance and Criminal Law' in this issue.

${ }^{100}$ Marshall, Human Rights Law and Personal Identity (n 9) 18.
} 
ever be a girl?' Paul's mother says: 'He thinks it's madly unfair that he's born the way he is. He's unhappy and hurt because he has to experience this. ... He just wants to be normal, and most of all, to just be a boy. He wishes he had been born a boy so he was spared from all this.' Daniel puts it this way: 'I don't want trans to be a big part of me. I try to just be a boy like everyone else.' The mothers describe their children's wish to be 'normal' and like everyone else. The children focus on gender reassignment treatment, such as puberty suppression hormones, hormones, and surgery. At the same time, Christine connects gender reassignment surgery with legal gender recognition. This might imply that surgery and change of legal gender will eradicate her view of herself as 'abnormal'. This cannot be detached from the gender borders under Norwegian law, which define gendered legal bodies in terms of the presence or lack of testis or ovaries. Possibly, Christine and Paul would have regarded their bodies as less 'abnormal' if the legal categories of gender were open to all bodies and identities, so that their bodies would have caused them less fear and prejudice and allowed them to have higher self-esteem. This demonstrates the interrelation between the social and legal spheres.

\section{Self-confidence strategies}

The devaluing of some life-styles in the way the narratives suggest, can, as Honneth puts it, lead to:

loss of self-esteem - that is, he is no longer in a position to conceive of himself as a being whose characteristic traits and abilities are worthy of esteem. [T] he person is deprived of the form of recognition that is expressed in society's approval of a type of self-realization that the person had only been able to acquire through an arduous process involving encouragement in the form of group solidarity. ${ }^{101}$

Self-confidence strategies developed to meet prejudice can take the form of empowerment from parents, through others and from oneself. The first of these can be seen when, faced with their children's unhappiness at being born the way they were, the two mothers try to convince them that they are special and that they can use their difference for something positive. They try to strengthen their self-confidence so that they can deal with the prejudice they are most likely to meet in Norwegian society today.

The second option is building self-confidence via other people. Daniel describes how much it means to him to help and support other transgender people. He also emphasises the importance of supportive comments from strangers and how these empower him. In addition, all the informants emphasise the importance of normalisation through the media and TV

\footnotetext{
${ }^{101}$ Honneth, 'Integrity and Disrespect’ (n 69) 191-192.
} 
series like 'Born in the wrong body'. The mothers say that role models have helped both their child and themselves to feel confident that what they are doing is right. Paul's mother says:

I believe that both given that the focus was on this [issue], and the fact that it was normalised, that those who watched the series could see that they [the cast] were normal people. They were not freaks, they were completely normal. For us and not least for [Paul], this was extremely important. I doubt whether he otherwise would have dared [to be open with us].

The presence of supportive people, and the feeling of being important and valued strengthen their self-esteem.

The third option is self-empowerment, the importance of which Daniel emphasises. He tries to focus on feeling good about himself and his positive experiences, rather than on the harassment and fear he has experienced. However, he says that he feels that other people respect him for who he is, but that he is not quite sure what he needs in order to feel respected and he does not search for recognition. He says:

Lately, I've actually tried not to feel accepted because if I have to go and wait for everyone's recognition, then I feel that I will be too dependent on it in order to feel good. So, I try to forget about it and just try to be happy with myself instead, if you get what I mean. It sounds strange because it's good to get recognition, but the problem is what if you don't?

I see this as his strategy to overcome the prejudice he meets, which he talks about too. Negative comments about transgender people make him wonder whether there is something wrong with him, but in order to overcome prejudice, he focuses on empowering himself. According to Daniel, people are more likely to recognise him if he feels good about himself.

\section{IV.iv The struggle for recognition: How the three spheres interrelate}

Honneth's theory and the categorisation of the narratives into the three spheres show that the spheres intertwine. It becomes clear that, for example, recognition by one's family alone is not enough if recognition is otherwise lacking. The struggle for recognition, though Daniel says he does not actively seek recognition from others, is common to all three stories. Except for the misrecognition Daniel experiences from his father, the narratives portray children whose emotional needs are mostly met in the private sphere by recognition from family and friends. This makes possible the development of self-confidence. The experience of recognition was a precondition for Christine, Paul, and Daniel to be open outside their closest family. But due to their gender identity, they cannot follow the ontogenetic developmental stages to reach full self-realisation. No matter how supportive their parents are, none of them can obtain the maximum amount of self-respect available through equal rights. Denial of their rights and the feeling they are devalued by the state, make it impossible for them to obtain 
recognition in either the legal or the social spheres. The law itself subordinates their bodies by limiting their ability to freely shape their identity. Their dignity and autonomy as human persons are not recognised. Their struggle for recognition fails here. This lack of recognition in the social sphere and their struggle to develop self-esteem are influenced by the exclusion of their identities in the legal sphere. They fear misrecognition from others if they disclose their gender history, because of prejudice and gender norms embedded in Norwegian society. At the same time, the normalisation of being transgender and the dissemination of information through, for example, TV series, impacted on the feeling of recognition in the private sphere. The narratives demonstrate how social recognition cannot be obtained without recognition in the legal sphere, but also that being open in the private sphere is influenced by social values. In this sense, Honneth's theory of recognition as an ontogenetic developmental stage to achieve a good life, seems to coincide with the narratives, but all spheres seem to interrelate and do not merely function as stages.

\section{Increased Self-Determination or Abolition of Legal Gender?}

In the following, I present two alternative scenarios which could improve Paul, Christine, and Daniel's self-relation: (1) allowing children to change their legal gender, or (2) abolishing legal gender. I discuss the alternatives with regard to Paul, Christine, and Daniel and their right to privacy and non-discrimination.

A growing number of states have abolished medical requirements for a change of legal gender. ${ }^{102}$ As mentioned in the introduction to this article, Norway is in the process of adopting its first law on changing legal gender, which will not require any medical interventions for legal change. For that reason, I omit medical requirements in the following discussion.

\section{V.i Granting minors the right to change legal gender and maintaining two legal genders}

Up until now, the implicit age limit of 18 years has been justified on the basis of medical requirements. The abolition of the medical requirements therefore removes the justification for the age limit for change of legal gender. The legal proposal suggests an age limit of 16 for changing legal gender without parental consent; children between the ages of seven and 16 would need parental consent.

The suggested age limit of seven would mean that Paul and Christine could change their legal gender. Both of them have parents who support them and believe that they are capable of making this decision themselves. The first option outlined above complies with their right to respect for a private life as enshrined in article 8 of ECHR and article 16 of CRC and to

\footnotetext{
${ }^{102}$ Among others: Sweden, Denmark, Malta, Argentina, and Germany.
} 
protection against discrimination in accordance with article 14 in conjunction with article 8 of ECHR and article 2 of the CRC. This option ensures their right to privacy and enables them to control whether or not other people can acquire information about their gender history. Unwanted disclosure of gender identity can violate the right to respect for one's private life under article 8 if the requirements prescribed in article 8 (2) are not fulfilled. They will be able to freely shape their identity. This option means they can have the legal gender that corresponds with their gender identity, and therefore not be subjected to different treatment from cisgender people.

Daniel, who does not want to undergo a complete gender confirmation treatment, would also be able to obtain legal recognition of his gender identity. He is over the age of majority, but the first option means that he could have changed his legal gender at the age of 16, even though he lacked the support of his father. This alternative gives minors over the age of 16 self-determination on matters of legal gender. This matches the general rule regarding selfdetermination from the age of 16 on health care matters. ${ }^{103}$

Some would argue that minors below the age of 16 are not competent to make the decision to change their legal gender at such an early stage of life. This objection implies that changing legal gender is a more serious decision than the child's decision to be open about their gender identity and break gender norms. This line of argumentation is based on a misconception. A Swedish inquiry dismisses the objection as follows:

The difficulty of a decision taken about a person's legal gender is, in legal and formal terms, minor because it only concerns a change of personal identity number. The difficulty could rather be said to lie in a young person actively choosing to go against the norms and ideas that dominate in a heteronormative society. ${ }^{104}$

In Norway, legal gender has little bearing on having specific rights or duties. Indeed, the Nordic countries have a tradition of making the wording of acts gender neutral. ${ }^{105}$ General conscription, retirement age, and criminal legislation are all gender neutral. Legal gender, on the other hand, is very visible in everyday life. Legal gender is shown in identity documents such as driving licences, passports, and bank cards, which may mean that the holder risks falling prey to discrimination or hate crime if there is a mismatch between the ID card and gender expression.

\footnotetext{
${ }^{103}$ Act No 63 of 2 July 1999 relating to Patients’ Rights (the Patients’ Right Act) s 4-3 para 1b.

104 Juridisk kön och medisinsk könskorrigering (SOU 91:14) 29-30.

${ }^{105}$ Ragnhild Hennum, 'Kjønnslikestilling på ville veier - kan kjønnsnøytrale krisesentre forsvares?' in Beatrice Halsaa and Anne Hellum (eds), Rettferdighet (Universitetsforlaget, 2010) 137.
} 
A similar objection is the risk that children might change their minds, either while going through puberty or later in life. This objection can also be dismissed. Since the legal implications of a change of legal gender is minor, changing one's mind after the fact will be of little significance, as long as the law is open to further changes of legal gender. Further, the risk of the exploitation of rights is minor. Few rights or duties are gender specific, and as mentioned above, going against the heteronormativity of society is probably more difficult than what is involved in changing legal gender. Lack of this possibility could mean that the child's life is put on hold, with the suppression of gender identity and negative implications this could have on their health. ${ }^{106}$

At first sight, lowering the age limit seems to be a good solution since it encompasses children's rights to a greater extent, but this option excludes children who lack the support of their parents. Lack of parental support precludes legal gender recognition. The narratives presented in this article are not representative of all transgender children. Many children experience lack of understanding and support from their parents. Some run away from their homes or break with their parents. ${ }^{107}$ The consent of these parents or legal guardians is difficult to obtain. ${ }^{108}$

One may ask whether it is in accordance with the rights of a gender non-conforming child not to be able to change legal gender - or whether parental consent is a justifiable requirement for legal recognition of the gender identity of children under 16 . As demonstrated in subsection II.ii, according to the ECtHR's jurisprudence, gender identity falls within the scope of a private life under article 8 of the ECHR. The provision gives, at the outset, the right to be legally recognised with dignity and integrity, in accordance with one's gender identity - in other words, the legal entitlement to personal freedom. Marshall argues that the Court's conception of freedom can be understood as self-creation or self-determination, meaning 'the freedom to be and become the person one chooses, while acknowledging that this happens in a societal context and must not harm others.' ${ }^{109}$ In the case of gender non-conforming children and adolescents, their rights must be weighed against the rights of their parents or legal guardians. This tension between these conflicting rights is problematic for gender nonconforming children, as well as for every other child, since parental rights can trump the interest of the child. Martha Albertson Fineman argues that all children face the structural disadvantage 'that parents are privileged in the organization of the family and children's

\footnotetext{
${ }^{106}$ Larsson and others (n 89) 237.

${ }^{107}$ Frida Darj \& Hedvig Nathorst-Böös, ‘Är du kille eller tjei?’ - en intervjustudie om unge transpersoners livsvillkor' (2008).

${ }^{108}$ In the Norwegian law proposal, it is not suggested that consent from a third party be introduced as an alternative to parental consent. The Ministry of Health and Care Services (n 7) para 7.2.1 and 7.2.2.

${ }^{109}$ Marshall, Personal Freedom Through Human Rights Law? (n 23) 121.
} 
interests, both as children and as future adults, and are sometimes compromised as a result., ${ }^{, 10}$ According to Fineman, this cannot be justified if the state has a responsibility to all its citizens and an interest in the adults the children are likely to become. ${ }^{111}$ At the same time, the narratives presented in this article, and Honneth's theory of recognition, show that children are dependent upon support from their parents - both in terms of receiving their rights and forming their identity. Children will face difficulties in forming their identity if their selfconfidence is not strengthened with the help of their parents - or others with whom they feel a similar intersubjective emotional relation.

The Convention on the Rights of the Child does not give children a right to selfdetermination. It does, however, assure children the right to express their views and to be heard, which is vital for the recognition of children as autonomous human beings. ${ }^{112}$ The Committee on the Rights of the Child has expressed concern, and urged states to end the categorisation of citizens based on religion and ethnic origin in passports and other identity documents. The committee has also emphasised that children's right to privacy and nondiscrimination can be violated by such categorisation. ${ }^{113}$ Similarly, legal gender can violate children's right to privacy and non-discrimination. As demonstrated in part IV, children may face discrimination and harassment because of their legal gender.

In addition, the increased self-determination scenario implies a reconstitution and continuation of a dualistic and biological gender regime in Norwegian law. Each person's life will start with the biological determination of gender for legal purposes. This reconstitutes gender as fixed and innate, rather than fluid and performative and goes against the fact that these legal categories embrace performativity and fluidity at a certain prescribed age when change of legal gender is allowed. Demanding recognition by the state could lead to new social hierarchies, and new social outcasts could emerge. ${ }^{114}$ An open, but dualistic, gender regime would exclude those who identify as neither man nor woman, or both, or fluid etc. In a Swedish inquiry conducted in 2014, 206 out of 798 respondents reported that they could not change their legal gender because the gender they preferred did not exist in Sweden. ${ }^{115}$

\section{V.ii Abolish legal gender?}

\footnotetext{
${ }^{110}$ Fineman (n 5) 122.

111 Ibid.

${ }^{112}$ Kirsten Sandberg, 'Barns rett til å bli hørt' in Høstmælingen, Kjørholt and Sandberg (n 41) 91; Lena R. L. Bendiksen and Trude Haugli, Sentrale emner i barneretten, (Universitetsforlaget, 2014) 42.

${ }^{113}$ Hodgkin and Newell (n 39) 204.

114 Judith Butler, 'Is kinship always already heterosexual?' (2002) 13(1) differences: A Journal of Feminist Cultural Studies, 14, 26.

${ }^{115}$ Folkhälsomyndigheten ( n 6) 25.
} 
In order to avoid discriminating between children who have the support of their parents and those who do not, as well as differential treatment on the grounds of age, the abolition of legal gender could be a solution, but is abolition feasible? Moreover, would it be a good solution?

This begs the question: what are the reasons behind introducing gender for legal purposes? In Norway, the national identity number was introduced because the increased number of taxpayers required a new method to differentiate between taxpayers. ${ }^{116}$ It has also been argued that legal gender is significant for the purpose of statistics. ${ }^{117}$ Both of these arguments can be dismissed. Today, decades after its introduction, new and better methods for identification have been adopted. Norwegian passports of people over twelve contain the holder's fingerprints. ${ }^{118}$ In addition, it can be argued that legal gender, as a tool for identifying individuals is rather unreliable. Since an increased number of jurisdictions are abolishing medical requirements for changing legal gender, legal gender becomes somewhat moot for the purpose of identification. The different legal genders will include a multitude of bodies and identities and therefore add little information. Citizens of a state can also be identified by the use of gender-neutral identity numbers. ${ }^{119}$ As far as statistics are concerned, arguably statistical reliability would increase were the data based on the respondents' gender identity or social gender rather than legal gender.

As mentioned above, under Norwegian law, a limited amount of rights are gender-specific. ${ }^{120}$ To mention one more example, in 2008, the Norwegian Marriage Act was amended to include same-sex couples. ${ }^{121}$ It appears paradoxical that the law in one area liberates itself from dualistic gender categories, while at the same time reconstituting the dualistic gender regime for the youngest and most vulnerable individuals in society. With regard to this, retaining legal gender may mean that the law itself leads to infringement of the right to privacy of children below the age limit and of those who lack parental support. This is difficult to justify when the necessity for legal gender seems to be slight or non-existent. As mentioned above, the national identity number could be gender-neutral, while a third gender could be introduced for Norwegian passports. ${ }^{122}$

\footnotetext{
${ }^{116}$ Skatteetaten, Konseptvalgutredning: Ny Personidentifikator i Folkeregisteret (30 June 2014) 23.

${ }^{117}$ Letter from The Directorate of Health to the Ministry of Health and Care Services (1 October 2012) 15.

${ }^{118}$ Forskrift om pass (FOR-1999-12-09-1263) s 5. See also Council Regulation (EC) 2252/2004 of 13 December 2004 on standards for security features and biometrics in passports and travel documents issued by member states, article 1(2), which requires fingerprints in EU passports.

119 This has been suggested in Norway. Skatteetaten. 'Konseptvalgutredning: Ny personidentifikator i

Folkeregisteret' (Version 1.0. 30 June 2014).

${ }^{120}$ With the upcoming abolishment of medical requirements for change of legal gender, both legal men and legal women will hold rights concerning pregnancy and birth. This will not be limited to legal women.

${ }^{121}$ Act No 47 of 4 July 1991on marriage s 1.

${ }^{122}$ See the International Civil Aviation Organization standards for passport. A passport must include either M (male), F (female) or X (unspecified).
} 


\section{Conclusion}

Norwegian laws and regulations are to a great extent gender-neutral, but the approach taken in this article has demonstrated how the heteronormativity of laws nevertheless influences transgender children as possessors of rights and their everyday life. Legal gender determines which identities and bodies are included or excluded from Norwegian society. These gender borders impact on transgender young people's everyday life. As demonstrated, it is impossible for gender non-conforming children to follow the ontogenetic developmental stages to achieve full self-realisation in accordance with Honneth's theory of recognition. The three stories show how the three spheres of recognition interrelate, and how Honneth's theory can be useful in showing that interrelation is important for a feeling of recognition in gender non-conforming children's everyday life and for the formation of their identity. Children with supportive parents and family can attain self-confidence but not self-respect. A lower age limit for change of legal gender could change this, but it would be necessary for their parents to give their consent. A legal gender in accordance with their gender identity would render their gender history less visible to strangers and society. This could have an effect on the level of harassment and discrimination they suffer and increase their chance of achieving selfesteem. Full self-realisation and a good life would be attainable for some gender nonconforming children, but not for all children. Abolishing legal gender might be a good solution by removing the differences legal gender creates between children who have supportive parents and those who do not, but the question is whether society is ready to diminish the presence of gender. Removal of legal gender will not necessarily mean that gender non-conforming children would reach full self-realisation in accordance with Honneth's theory. Removal of legal gender would however mean there was one less obstacle. If the law does not exclude certain identities or create otherness, this may change attitudes in society and may improve children's feeling of self-esteem, eventually opening the way to full self-realisation for gender non-conforming people in accordance with their right to respect for their private life and non-discrimination. 